\title{
Upaya Peningkatan Kompetensi Guru dalam Pengembangan Instrumen Penilaian Tes Tertulis Pembelajaran Tematik pada Penilaian Akhir Semester Melalui Pendidikan dan Latihan
}

\author{
Triyono ${ }^{1}$ \\ ${ }^{I}$ SLBN Prof. Dr. Sri Soedewi Masjchun Sofwan, S.H Jambi, Indonesia \\ Email: triyonojbi1963@gmail.com
}

\section{INFORMASI ARTIKEL}

Terkirim13-Oktober-2021

Revisi 21-Oktober-2021

Diterima 26-Oktober-2021

Kata kunci:

Penilaian, test tertulis, tematik, pendidikan dan latihan.

\begin{abstract}
ABSTRAK
Penelitian ini bertujuan untuk mengetahui apakah dengan pendidikan dan pelatihan dapat meningkatkan kompetensi guru dalam mengembangkan instrumen penilaian tes tertulis pembelajaran tematik pada penilaian akhir semester.Penelitian dilaksanakan di SLBN Prof. Dr. Sri Soedewi MS, S.H. Jambi. Penelitian ini merupakan penelitian tindakan sekolah yang dilaksanakan dalam 2 siklus. Penelitian ini juga merupakan penelitian deskriptif dengan menggunakan teknik analisis deskriptif kualitatif. Hasil penelitian ini menunjukkan bahwa Pendidikan dan pelatihan mempunyai dampak positif dalam meningkatkan kompetensi guru dalam mengembangkan instrumen penilaian tes tertulis pembelajaran tematik pada penilaian akhir semester. Hal ini dapat dilihat dari semakin mantapnya pemahaman dan penguasaan peserta diklat (Guru) terhadap materi yang telah disampaikan oleh narasumber, dimana ketuntasan belajar (pelatihan) meningkat dari siklkus I dan II yaitu masing-masing $66,07 \%$ dan $87,50 \%$. Pada siklus II, ketuntasan belajar secara klasikal telah tercapai.
\end{abstract}

(7) (2) This is an open access article distributed under the Creative Commons 4.0 Attribution License, This license lets others remix, tweak, and build upon your work even for commercial This is an open access article distributed under the Creative Commons 4.0 Attribution License, This license lets others remix, tweak, and build
purposes, as long as they credit you and license their new creations under the identical terms @2018 by author and Universitas Negeri Padang.

\section{Pendahuluan}

Permendikbud nomor 16 tahun 2007 menegaskan bahwa seorang guru harus mempunyai 4 standar kompetensi yaitu kompetensi padagogik, kepribadian, sosial dan professional. Keempat kompetensi tersebut harus teintegrasi dalam kinerja seorang guru. Kompetensi pedagogik guru meliputi beberapa kompetensi inti, salah satu diantaranya adalah menyelenggarakan penilaian dan evaluasi hasil belajar.

Oleh karena itu penilaian merupakan hal penting yang harus dikuasi oleh seorang guru. Seiring dengan implementasi kurikulum 2013 pendidikan khusus di SLB di mana pembelajarannya sebagian besar adalah pembelajaran tematik mulai dari SDLB, SMPLB dan SMALB, maka seorang guru harus mampu mengembangkan instrumen penilaian sesuai dengan konsep pembelajaran tematik mulai dari menganalisis $\mathrm{KD}$, menyusun kisi-kisi sesuai $\mathrm{KD}$, menulis soal berdasarkan kisi-kisi dan mengacu pada kaidah penulisan soal, menyusun pedoman penskoran, dan melakukan penskoran berdasarkan pedoman penskoran.

Kondisi riil di lapangan ditemukan bahwa kompetensi guru SLBN Prof. Dr. Sri Soedewi MS, S.H. Jambi dalam mengembangkan instrumen Penilaian Akhir Semester (PAS) pembelajaran tematik masih sangat rendah. Sebagai buktinya adalah hasil supervisi pembelajaran (kelas) bulan Juni 2020 oleh kepala sekolah. Hasil supervisi menunjukkan bahwa sebanyak 56 dari 62 guru kelas dalam menyelenggarakan penilaian akhir semester (PAS) genap tahun pelajaran 2019/2020 masih salah 
karena soal dibuat dalam bentuk mata pelajaran yang berdiri sendiri-sendiri. Hal ini sepertinya tidak rasional di mana proses pembelajarannya tematik terpadu, giliran pada penilaian tertulisnya berupa mata pelajaran - mata pelajaran yang berdiri sendiri. Mengapa tidak rasional? Ada beberapa alasan kajian rasional sebagai berikut: (1) Jika kita kaitkan dengan jadwal pelajaran jelas tidak rasional, di mana jadwal tiap harinya berupa tema-tema dan gurunya mengajarkan tema-tema (bukan mata pelajaran) sesuai dengan jadwal yang dibuat, giliran pada tes tertulis pada Penilian Akhir Semester (PAS) berupa mata pelajaran-mata pelajaran. Bukankah hal ini membingungkan siswa?, (2) Jika tes tertulis pada penilaian akhir semester berupa mata pelajar-mata pelajaran berarti tiap hari siswa harus belajar 5 buku tema (tema 1-5 pada semester ganjil atau tema 6-10 pada semester genap). Alangkah beratnya siswa tiap hari belajar 5 buku sedangkan belajar 1 buku saja sudah lumayan berat; dan (3) Selain siswa menjadi berat tentu juga bingung karena selain tiap hari siswa harus belajar 5 buku dan ironisnya lagi pada tiap buku tema itu kan tidak ada muncul nama mata pelajaran - mata pelajaran, tentunya siswa bingung kan, yang mana PPKn, yang mana IPS, yang mana IPA, yang mana Bahasa Indonesia, yang mana SBDP karena memang tidak disebut kan secara eksplisit. Bukankah hal ini membingungkan siswa? Jadi selain siswa berat tiap hari harus belajar 5 buku, siswa bingung memilih mata pelajaran - mata pelajaran yang harus dipelajari karena memang tidak disebutkan secara eksplisit di buku tema itu. Bukankah pembelajaran harus menjadikan siswa lebih jelas dan paham bukan membuat siswa bingung. Hal ini bertentangan dengan konsep pembelajarn tematik. Oleh karena itu soal tes tertulis penilaian akhir semester seharusnya dalam bentuk tema.

Depdkinas (2005) menyatakan bahwa penilaian tes tertulis dalam pembelajaran tematik dapat dilakukan dengan 2 (dua) cara, yaitu (1) penilaian tes tertulis untuk tiap-tiap mata pelajaran dengan menyebutkan nama mata pelajaran, dan (2) penilaian tes tertulis dengan tanpa menyebutkan nama mata pelajaran, tetapi guru mengetahui tujuan yang ingin dicapai berdasarkan indicator yang telah ditetapkan untuk masing-masing mata pelajaran. Lebih lanjut dalam buku ini dijelaskan bahwa pada cara pertama walaupun nama mata pelajaran disebutkan namun identitas soal tertulis tersebut tetap tema yang di dalamnya terdiri dari beberapa mata pelajaran yang tercakup dalam tema tersebut. Oleh karena itu jadwal Penilaian Akhir Semester (PAS) berupa tema-tema bukan mata pelajaran, misalnya hari pertama tema 1 , hari kedua tema 2 , hari ketiga tema 3 , hari keempat tema 4 dan hari kelima tema 5.

Lebih lanjut Kemendikbud 2016, menyatakan bahwa penilaian akhir semester dilaksanakan setelah pembelajaran empat tema selesai (untuk kelas I, II, III) atau pembelajaran lima tema selesai (untuk siswa kelas IV, V dan VI). Pelaksanaan akhir semester diatur sesuai jadwal berdasarkan tema dan muatan mata pelajaran. Berdasarkan kedua teori ini dapat disimpulkan bahwa penilaian tes tertulis pada penilaian akhir semester, soal-soalnya harus dibuat atau ditulis dalam bentuk soal tematik (bukan mata pelajaran yang berdiri sendiri) dan jadwal pelaksanaannya pun tentu berupa tema-tema, bukan mata pelajaran.

Berdasarkan latar belakang masalah maka perlu diadakan Pendidikan dan pelatihan dalam mengembangkan instrumen penilaian tes tertulis pembelajaran teamtik pada penilaian akhir semester pembelajaran tematik agar tidak terjadi kesalahan yang fatal. Oleh karena itu perlu diadakan penelitian untuk meningkatkan kompetensi guru-guru tersebut dengan judul "Upaya Peningkatan Kompetensi 
Guru dalam Pengembangkan Instrumen Penilaian Tes Tertulis Pembelajaran Tematik pada Penilaian Akhir Semester melalui Pendidikan dan Pelatihan di SLBN Prof. Dr. Sri Soedewi Jambi Tahun Pelajaran 2020/2021."

Bertitik tolak dari latar belakang di atas maka penulis dapat merumuskan permasalahan sebagai berikut: "Bagaimanakah peningkatan kompetensi guru dalam mengembangkan instrumen penilaian akhir semester pembelajaran tematik melalui pelatihan bagi guru SLBN Prof. Dr. Sri Soedewi MS, S.H. Jambi semester ganjil tahun pelajaran 2020/2021? Sedangkan tujuan penelitian ini adalah untuk mengetahui peningkatan kompetensi guru dalam mengembangkan instrumen penilaian tes tertulis pembelajaran tematik pada penilaian akhir semester setelah diberikan pelatihan.

\section{Metode}

Penelitian ini merupakan penelitian tindakan (action research), karena penelitian dilakukan untuk memecahkan masalah kompetensi guru di sekolah. Penelitian ini merupakan penelitian deskriptif, sebab menggambarkan bagaimana suatu teknik pelatihan diterapkan dan bagaimana hasil yang inginkan dapat dicapai.Dalam penelitian ini menggunakan bentuk penelitian tindakan kepala sekolah sebagai peneliti, namun karena ini penelitian tindakan sekolah maka dinamakan bentuk penelitian Tindakan kepala sekolah sebagai peneliti. Tujuan utama penelitian tindakan sekolah ini adalah untuk meningkatkan kompetensi guru dalam mengembangkan instrumen penilaian tes tertulis pembelajaran tematik pada penilaian akhir semester, lebih khusus lagi pada penilaian pengetahuan. Tempat penelitian adalah tempat yang digunakan dalam melakukan penelitian untuk memperoleh data yang diinginkan. Penelitian ini bertempat di SLBN Prof. Dr. Sri Soedewi MS, S.H. Jambi. Waktu penelitian adalah waktu berlangsungnya atau saat penelitian ini diselenggarakan. Penelitian ini dilaksanakan pada bulan September 2020.Populasi dari penelitian ini adalah guru-guru SLB Negeri Prof. Dr. Sri Soedewi MS, S.H. Jambi tahun pelajaran 2020/2021 yang berjumlah 82 orang. Sedangkan yang menjadi sampel penelitian ini adalah guru kelas SDLB, SMPLB, dan SMALB berjumlah 56 orang.

Teknik pengumpulan data dari penelitian ini yaitu dengan teknik observasi dan teknis tes. Untuk mengethui keefektifan suatu keberhasilan Pendidikan dan pelatihan ini perlu diadakan Analisa data. Pada penelitian ini menggunakan menggunakan Teknik analisis deskriptif kualitatif, yaitu suatu metode penenltian yang bersifat menggambarkan kenyataan atau fakta sesuai dengan data yang telah diperoleh dengan tujuan untuk mengetahui peningkatan kompetensi guru penilaian pembelajaran tematik pada penilaian akhir semester setelah diberikan Pendidikan dan pelatihan.

\section{Hasil Penelitian dan Pembahasan}

Penelitian dilaksanakan dalam 2 siklus, masing-masing siklus meliputi kegiatan pengamatan aktivitas peserta diklat, pengamatan aktivitas narasumber dan tes atau evaluasi hasil belajar. Pengamatan dilakukan oleh 2 pengamat. Hasil penelitian akan disajikan sebagai berikut:

Tabel 1 Data Hasil Pengamatan Aktivitas Peserta Pendidikan dan Pelatihan siklus I dan II 


\begin{tabular}{lcc}
\hline Aktivitas Peserta Diklat & Siklus I & Siklus II \\
\hline Jumlah Nilai & 23,5 & 31,5 \\
\hline Rata-rata & 2,61 & 3,56 \\
\hline Prosentase & $65,28 \%$ & $88,89 \%$ \\
\hline Kategori & Cukup baik & Baik \\
\hline
\end{tabular}

Dari tabel 1 di atas bisa kita lihat bahwa ada peningkatan aktivitas peserta diklat dalam pembelajaran dari siklus I ke siklus II, di mana pada siklus I aktivitas peserta diklat memperoleh nilai 65,28 dengan kategori cukup baik, meningkat menjadi 88,89\% dengan kategori baik.

Tabel 2 Data Hasil Tes Peserta diklat pada Pendidikan dan Pelatihan

\begin{tabular}{lcc}
\hline Hasil Tes & Siklus I & Siklus II \\
\hline Jumlah skor ideal & 5.600 & 5.600 \\
\hline Jumlah skor tercapai & 3.860 & 4.060 \\
\hline Rata-rata skor tercapai & 68,93 & 72,50 \\
\hline Prosentase ketuntasan & $66,07 \%$ & $87,50 \%$ \\
\hline
\end{tabular}

Peningkatan hasil penelitian juga terjadi pada tes evaluasi hasil belajar, di mana pada siklus I nilai rata-rata diperoleh 68,93 dengan prosentasi ketuntasan 66,07\% meningkat pada siklus II menjadi 72,50 dengan prosentase ketuntasan 87,50\%. Pada siklus I ketuntasan belajar secara klasikal belum tercapai karena peserta diklat yang memperoleh nilai $\geq 65$ hanya sebesar 66,07, lebih kecil dari persentase ketuntasan yang dikehendaki, yaitu $85 \%$. Hal ini karena penilaian pembelajaran tematik pada penilaian akhir semester bagi mereka masih belum paham. Sedangkan pada siklus II ketuntasan belajar secara klasikal sudah tercapai yaitu $87,50 \%$ melebihi prosentase ketuntasan yaitu $85 \%$.

Tabel 3 Data Hasil Pengamatan Aktivitas Narasumber Pendidikan dan pelatihan

\begin{tabular}{lcc}
\hline Aktivitas Narasumber & Siklus I & Siklus II \\
\hline Jumlah Nilai & 24,5 & 32,5 \\
\hline Rata-rata & 2,72 & 3,61 \\
\hline Prosentase & $68,06 \%$ & $90,28 \%$ \\
\hline Kategori & Cukup baik & Baik \\
\hline
\end{tabular}

Tabel 3 menunjukkan bahwa aktivitas narasumber juga mengalami peningkatan yang signifikan dari siklus I ke siklus II. Pada siklus I aktivitas narasumber memperoleh skor 68\% dengan kategori cukup baik, meningkat menjadi 90,28\% pada siklus II. Peningkatan ini menunjukkan bahwa narasumber bisa mengelola kelas dengan baik.

Hasil penelitian ini menunjukkan bahwa Pendidikan dan pelatihan mempunyai dampak positif dalam meningkatkan kompetensi guru dalam mengembangkan instrumen penilaian tes tertulis pembelajaran tematik pada penilaian akhir semester yang meliputi pembuatan kisi-kisi soal tematik, soal tematik, Menyusun pedoman penskoran, pengolahan nilai, dan penyusunan jadwal penilaian akhir 
semester. Hal ini dapat dilihat dari semakin mantapnya pemahaman dan penguasaan peserta diklat (Guru) terhadap materi yang telah disampaikan oleh narasumber selama ini dimana ketuntasan hasil pelatihan meningkat dari siklkus I dan II yaitu masing-masing 66,07\% dan 87,50\%. Pada siklus II, ketuntasan pelatihan siswa secara klasikal telah tercapai.

Kemampuan Narasumber dalam Mengelola Pendidikan dan Pelatihan

Berdasarkan analisis data diperoleh aktivitas peserta diklat dalam proses Pendidikan dan pelatihan dalam setiap siklus mengalami peningkatan. Hal ini berdampak positif terhadap proses mengingat kembali materi pelajaran yang telah diterima selama ini, yaitu dapat ditunjukkan dengan meningkatnya nilai rata-rata peserta diklat pada setiap diklat, yaitu dari 68,93 pada siklus I menjadi 72,50 pada siklus II.

Aktivitas Narasumber dan Peserta Diklat dalam Pendidikan dan Pelatihan

Berdasarkan analisis data diperoleh aktivitas peserta diklat dalam proses Pendidikan dan pelatihan, aktivitas peserta diklat meningkat dari siklus I ke siklus II dari kategori cukup ke baik pada siklus II. Jadi dapat dikatakan bahwa aktivitas peserta diklat dapat dikategorikan aktif. Sedangkan untuk aktivitas narasumber, selama Pendidikan dan pelatihan narasumber telah melaksanakan langkahlangkah pelatihan aktif dengan baik. Hal ini terlihat dari aktivitas narasumber, diantaranya membimbing dan mengamati peserta diklat dalam melakukan kegiatan, menjelaskan, memberi umpan balik/tes/tanya jawab yang mana persentasenya cukup besar.

\section{Kesimpulan}

Berdasarkan hasil penelitian yang telah dikemukakan pada sebelumnya, kesimpulan yang dapat ditarik pada penelitian ini adalah sebagai berikut: Pendidikan dan Pelatihan memiliki dampak positif dalam meningkatkan kompetensi guru dalam mengembangkan instrument penilaian akhir semester (PAS) bagi guru-guru kelas SLBN Prof. Dr. Sri Soedewi Jambi yang ditandai dengan peningkatan ketuntasan pelatihan peserta diklat (guru) dalam setiap siklus, yaitu siklus I (66,07\%), siklus II (87,50\%). Penyelenggaraan Pendidikan dan pelatihan mempunyai pengaruh positif, yaitu dapat meningkatkan kompetensi guru mengembangkan instrument penilaian akhir semester yang ditunjukkan dengan jawaban peserta diklat yang menyatakan bahwa mereka puas dan paham tentang penilaian tes tertulis pembelajaran tematik dan mereka sadar bahwa yang dilakukan selama ini salah, menyalahi konsep pembelajaran tematik.

\section{Daftar Rujukan}

Alex, Nitisemito. (2005). Manajemen Sumber Daya Manusia. Bandung: Pustaka Setia.

Arikunto, Suharsimi. (2002). Prosedur Penelitian Suatu Pendekatan Praktik. Jakarta:Rineka Cipta.

Depdiknas, (2005). Pembelajaran Tematik Kelas Awal Sekolah Dasar. Jakarta: Pusat Kurikulum Badan Penelitian dan Pengembangan,

Hajar, Ibnu. (2013). Panduan Lengkap Kurikulum Tematik. Jogjakarta: DIVA Press.

Kemendikbud.(2016). Panduan Penilaian Untuk Sekolah Dasar. Jakarta: Direktorat Pendidikan Dasar 
dan Menengah.

Kemdikbud.(2014). Panduan Pembelajaran Tematik Terpadu. Jakarta: Direktorat Pendidikan Dasar Dan Menengah.

Kemdikbud.(2014). Penilaian dalam Pembelajaran Tematik. Jakarta: Direktorat Jenderal Pendidikan Tinggi.

Majid, Abdul. (2014). Pembelajaran Tematik Terpadu. Bandung: PT Remaja Rosdakarya.

Sukidin, dkk. (2002). Manajemen Penelitian Tindakan kelas. Insan Cendikia. ., (2007). Permendikbud Nomor 16 Tahun 2007. 